\title{
Determination of Wind Energy Potential and its Implementation Concept for the Electricity Market in the Vojvodina Region (North Serbia) - An Overview
}

\author{
Micić Tanja ${ }^{A}, \mathrm{~B}$, Lukić Tin ${ }^{\mathrm{B}}$, Đorđević Jasmina ${ }^{\mathrm{B}}$, Basarin Biljana ${ }^{\mathrm{B}}$, Bjelajac Dajana ${ }^{\mathrm{A}, \mathrm{B}}$, \\ Hrnjak Ivana ${ }^{B}$, Marković $B$. Slobodan ${ }^{B}$, Sakulski Dušan ${ }^{C, D}$, Đerčan Bojan ${ }^{B}$, \\ Bubalo-Živković Milka', Pavić Dragoslav ${ }^{B}$, Lazić Lazar \\ Received: February 15, 2014 | Revised: February 24, 2014 | Accepted: April 9, 2014
}

\begin{abstract}
Renewable energy sources play an important role in the future not only for the European countries, but for many countries worldwide. Most cost-effective and reliable large wind energy conversion systems are becoming the main focus of wind energy research and technology development, all in order to make wind energy competitive with other more traditional sources of electrical energy like coal, gas and nuclear generation. Serbia, along with neighbouring countries, has a high potential for developing energy production from renewable energy sources. Wind energy in Serbia, despite its great potential, is only partly studied and insufficiently used. This study aims to provide summary of wind energy potentials in the region of Vojvodina, which is an important economic region in northern Serbia. Its existing electrical energy status is thoroughly investigated according to the recent developments of wind energy production on global, regional and local scale. The main purpose of this study is the implementation of energy efficiency concept with purpose of satisfying the needs of Serbian electricity market.
\end{abstract}

Key words: renewable energy sources, wind energy, electricity market, policy planning, Vojvodina, Serbia.

\section{Introduction}

There has been a significant increase in energy requirements due to rapid economic and technological developments in the $21^{\text {st }}$ century, especially in emerging countries (Baños et al 2011; Tükenmez, Demireli, 2012). The production of electrical energy has been mainly derived from limited natural sources, which causes fossil fuels to be highly consumed in the near future but many studies on electrical energy production with the use of renewable sources such as hydraulic, solar, wind, biomass and geothermal energy are providing a different perspective of energy saving, production and consumption at the same time (Kaygusuz, 2011). Renewable energy sources are very important for the future, not only of the European countries, but for many countries worldwide (Peidong et al 2009; Chen, 2007). It is not surprising how great the interest in wind potential is because its usage has many advantages. Most cost-

A Society of Young Researchers of Department for Geography, Tourism and Hotel Management, "Branislav Bukurov" Trg Dositeja Obradovića 3, 21000 Novi Sad, Serbia;

B University of Novi Sad, Faculty of Science, Department of Geography, Tourism and Hotel Management, Trg Dositeja Obradovića 3, 21000 Novi Sad, Serbia

c Department of Environmental Engineering and Occupational Safety and Health, Faculty of Technical Sciences, University of Novi Sad, Trg Dositeja Obradovića 6, 21000 Novi Sad, Serbia

D Disaster Management Training and Education Centre (DiMTEC), University of the Free State, 205 Nelson Mandela Drive, Park West, Bloemfontein, South Africa 


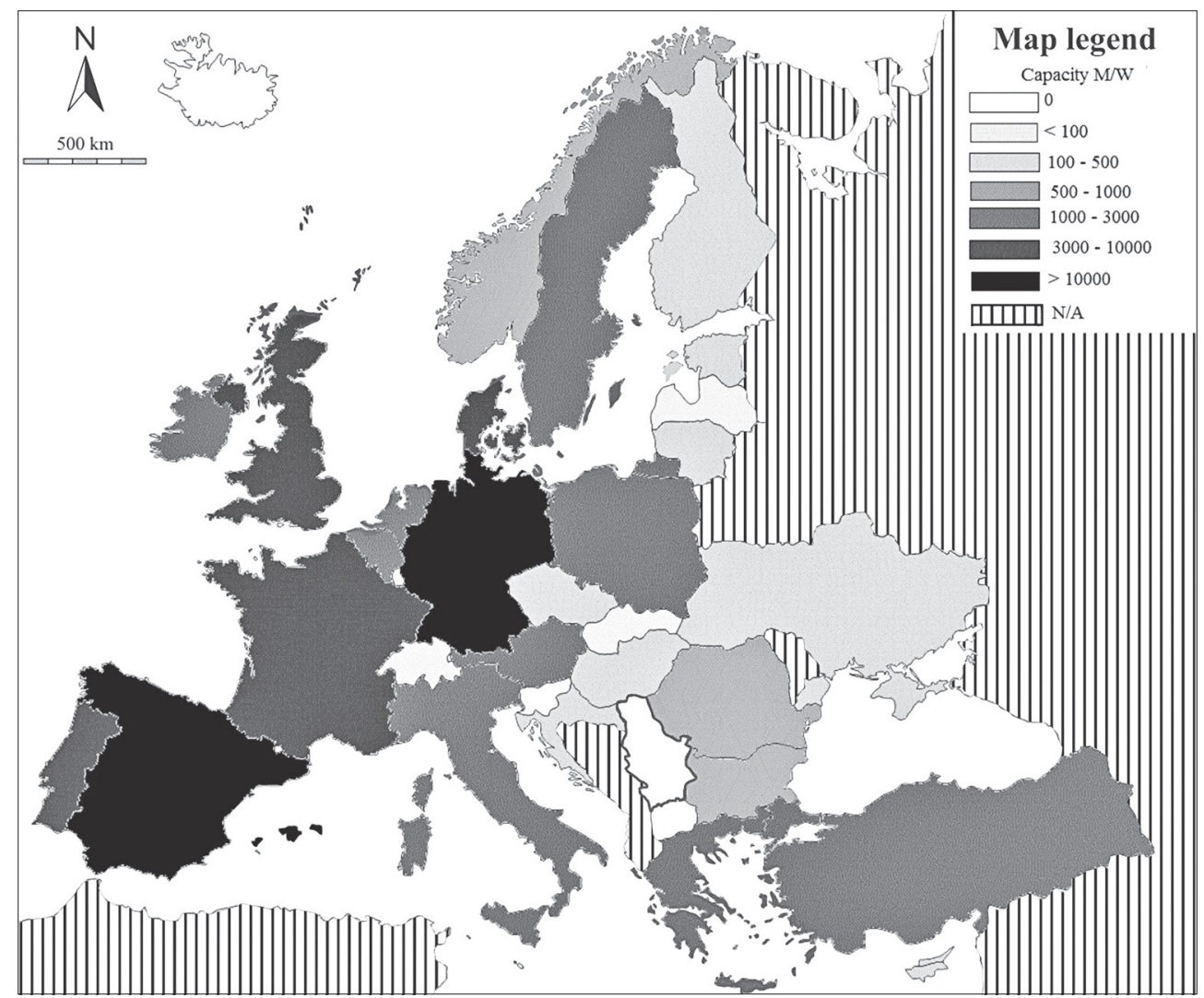

Figure 1. Wind power capacities installed in Europe by the end of 2012 with Serbia highlighted Source adapted from: EWEA, 2012

effective and reliable large wind energy conversion systems are becoming the main focus of wind energy technology development in order to make this type of energy competitive with the other, more traditional sources of electrical energy production from energents like coal, gas and nuclear generation ( $\mathrm{Li}$, Chen, 2009).

The European Wind Power Association (EWEA) has launched "No Fossil Fuels" campaign to show that the wind power alone can supply over one-fifth of the needs for electric energy in Europe by 2010 (Awerbuch, 2006). This would secure an effective solution to the energy crisis Europe is faced with, thus eliminating the uncertainty created by the rising oil prices on the global market (Gburčik et al, 2006). EWEA studies show that annual installations of wind power generators have increased steadily over the last 12 years from $3.2 \mathrm{GW}$ in 2000 to $11.9 \mathrm{GW}$ in 2012 , which represents an annual average market growth of $11.6 \%$ (EWEA, 2012). The same study confirms that the EU's total installed power capacity increased by $29.2 \mathrm{GW}$ net to $931.9 \mathrm{GW}$, with wind power increasing its share of installed capacity to $11.7 \mathrm{GW}$, and renewable capacity increasing its share up to $11.4 \%$ in contrast to $10.5 \%$ from the previous year. Also, the urgent need for the $\mathrm{EU}$ to move to a $30 \%$ greenhouse gas reduction target for 2020 in order to introduce an Emissions Performance Standard and to end decades of subsidies for new coal builds and its fuel is reflected in the fact that most of its power sectors continue to move away from oil fuels and nuclear consumption. A total of $931.9 \mathrm{GW}$ is now installed in the European Union and this data represent an increase in installed cumulative capacity of $11.4 \%$ compared to the previous year. Among the countries, Germany remains the EU country with the largest installed capacity followed by Spain, the UK and Italy. Fifteen Member States have more than 1 GW of installed capacity, including two newer Member States, Poland and Romania. Growth in onshore installations in countries such as Germany and Sweden along with offshore in the United Kingdom reflects strong performance from some emerging onshore markets in Eastern Europe. The wind capacity installed by the end of 2012 would, in a normal year, produce $231 \mathrm{TWh}$ of electricity which represents $7 \%$ of electricity consumption (up from 6.3\% the year before). Europe in general is giving a total production of 106.040 MW, while EU candidate countries such as Croatia ${ }^{1}$, Former Yugoslav Republic of Macedonia, Serbia and Turkey produce about 2.492 MW from wind energy. Although, Serbia stands in this group as a country of significant wind energy potentials, its production rate is "o" in term of installed capacities and renewable wind energy production (Figure 1).

\footnotetext{
1 The last EWEA report was published before Croatia became EU member (EWEA, 2012)
} 
Western Balkan countries (Serbia, Croatia, Bosnia and Herzegovina, Montenegro, Albania and Former Yugoslav Republic of Macedonia) have the highest energy intensities in Europe. Serbia, along with neighbouring countries, has a high potential for developing energy production from renewable energy sources. Although energy is a critical foundation for economic growth and social progress not only for Serbia but for all the Western Balkan countries, there are many constraints for renewable energy resources utilization and development in term of political, technological, financial, legislative and educational concepts for implementation purposes (Lalić et al, 2010).

The wind energy in Serbia is partly studied and not enough exploited despite its great potential (assessment of the wind energy share in total share of renewable energy potential is estimated to 0.19 million annually) (Golušin et al, 2006). This fact reflects not so bright ongoing situation in terms of its utilization for the needs of Serbia's energy sector. Similar trends are particularly present in the Vojvodina region (North Serbia), where renewable wind energy potential estimated to a $65 \mathrm{k}$ ten/year has a share of only $0.7 \%$ in total energy production (Energy Balance of the Autonomous Province of Vojvodina, 2010).

The aim of this paper is to provide an overview of the wind energy potentials in the region of Vojvodina, an important economic region in northern Serbia, with its existing electrical energy status investigated according to the recent developments of wind energy production on global, regional and local scales, with the main purpose of implementation concept of energy efficiency and needs of Serbia's electricity market.

\section{Vojvodina region - wind energy potential}

Vojvodina is a region in northern Serbia, located in the south-eastern part of Carpathian (Pannonian) Basin. It covers the total area of $21,500 \mathrm{~km}^{2}$ and has a population of about 2 million (about $27 \%$ of Serbia's total). The region is divided by the Danube, Tisza and Sava rivers into: Bačka in the northwest, Banat in the east and Srem in the southwest (a small part of the Mačva region is also located in the Srem District) (Dodić et al, 2010).

In Serbia, systematic measurements of wind potential have not been fully performed, and therefore there are no reliable data on the wind power potential (Wind Atlas of Vojvodina, 2008). Several papers (e.g. Gburčik et al, 2006; Golušin et al, 2006; Đurišić et al, 2007; Lalić et al, 2010; Dodić et al, 2010; Josimović, Pucar, 2010; Golušin, Munitlak-Ivanović, 2011; Komarov et al, 2012) along with certain studies on renewable energy potentials of Serbia (e.g. Wind Atlas of Vojvodina, 2008; Energy Balance of the Autonomous Prov- ince of Vojvodina, 2010; Energy Balance of the Autonomous Province of Vojvodina, 2009; Energy Balance of the Autonomous Province of Vojvodina, 2008; Strategy of Energy Development in the Republic of Serbia by 2015 - for the period 2007- 2012, 2005) initiated by the Ministry of Infrastructure and Energy, along with Provincial Secretariat for Energy and Mineral Resources of Vojvodina are bases for the assessment methodology and energy consumption planning in this region. The first study of the energetic potential of wind in Serbia was finished in 2002 for Electric Power Industry of Serbia. The energetic potential of wind in Serbia was estimated at approximately $1,300 \mathrm{MW}$, with potential annual production of electric power of 2.3 TWh (Wind Atlas of Vojvodina, 2008). The available wind energy in Serbia varies greatly from one region to another, showing substantial differences on local and sub-regional scales. The north-eastern part of Serbia is a region of special interest for perspective wind-plant construction (Lalić et al, 2010), with wind energy more available in lower areas than in higher ones. This phenomenon can be explained with a fact that the present winds are usually katabatic and have higher speed in descending. Thus, the north-eastern parts of Serbia (Vojvodina) represent a region of special interest with characteristic wind energy potential (see Figure 2). What is particularly interesting is the micro region of south and south-eastern Banat where the wind of dominant direction also has dominant speed, especially during the colder period of the year. The Vojvodina region is characterized by a strong southeast wind (Wind Atlas of Vojvodina, 2008) (Figure 2). This wind, whose descending component is stronger than the ascending, occurs simultaneously and is called "koshava". This local wind usually blows during the colder period of the year. The warmer period of the year is dominated by the winds from western quadrants (Atlas of solar and wind energetic potential in Serbia, 2007).

Deliblato Sands in the micro region of southern $\mathrm{Ba}-$ nat represents a good example of area characterized by a relatively effective wind potential, with the prevailing class 3 and class 4 winds. The wind potential is greater on the periphery of the Deliblato Sands and includes several micro locations in which a main annual wind velocity, measured at $50 \mathrm{~m}$, is above $6 \mathrm{~m} / \mathrm{s}$, while the main wind power density in these locations is about $300 \mathrm{~W} / \mathrm{m}^{2}$. This area is characterized by a strong southeast wind with maximum occurrence in autumn, winter and spring, while the summer winds are predominantly in west direction and considerably lower in intensity. Thus, these annual facts favour the construction of the wind power plants in this area. Also, sites near villages of Bavanište, Dolovo, Izbište, Parta and Grebenac along with sites in Alibu- 


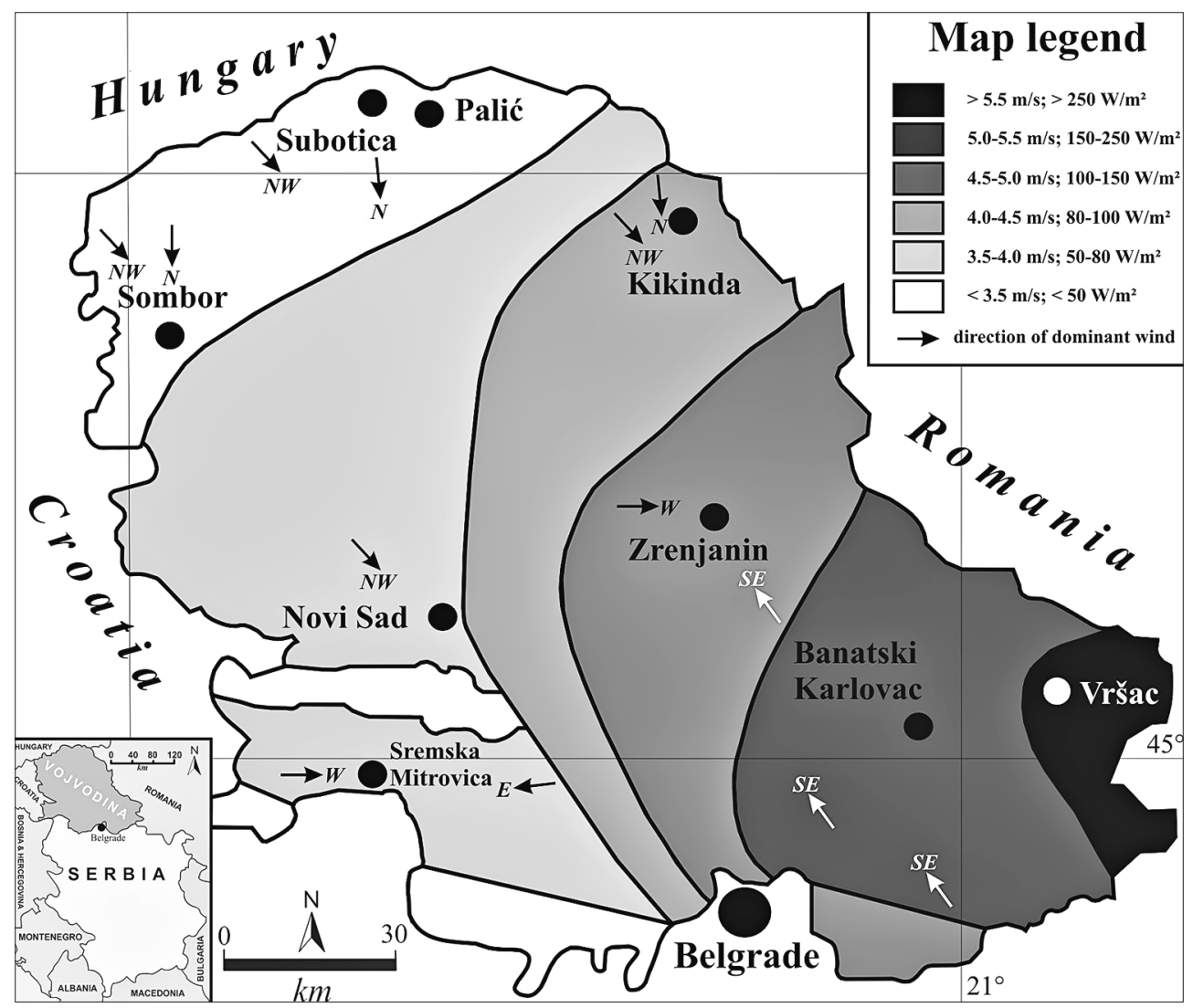

Figure 2. Average annual wind speeds and wind power map of Vojvodina region at $50 \mathrm{~m}$ height above ground level with directions of dominant winds

Source adapted from: Wind Atlas of Vojvodina, 2008; Đurišić et al, 2007; Atlas of solar and wind energetic potential in Serbia, 2007

nar and Bela Crkva municipalities are also very suitable for installation of the wind turbines (Golušin et al, 2006; Wind Atlas of Vojvodina, 2008; Josimović, Pucar, 2010; Đurišić et al, 2007). Furthermore, there is a plan for building a complex of 20 wind turbines in Irig, on the southern slopes of the Fruška Gora Mountain, in micro region of Srem. A similar study assumes the building of wind turbines in Inđija municipality, which would lead to the total projected installed capacity of $1.2 \mathrm{GW}$. Thus, it is necessary to investigate and measure the wind energy values on micro locations in order to obtain precise data on future benefits from the investments (Strategy of Energy Development in the Republic of Serbia by 2015 - for the period 2007- 2012, 2005). One of the estimation types may also be based on the main annual wind speed.

In case of available data on the main annual wind speed at the location, the wind frequency distribution is subject to Weibull's distribution according to which rough estimates on annual electric energy production $(\boldsymbol{E})$ of a wind power plant per a wind turbine surface unit, where $\boldsymbol{v}_{\text {avg }}(\mathrm{m} / \mathrm{s})$ stands for annual wind speed at the turbine axis (Wind Atlas of Vojvodina, 2008; Ilkilic, Turkbay, 2010).

$$
E=3.2 \cdot v_{\text {avg }}{ }^{3}\left[\mathrm{kWh} / \mathrm{m}^{2}\right]
$$

Vršački Breg in the Municipality of Vršac represents an area of annual wind speed which exceeds 5.5 $\mathrm{m} / \mathrm{s}(6.27 \mathrm{~m} / \mathrm{s})$ as presented in Figure 2. The above presented formula enables an approximate estimation of electric power produced by the installed wind power plant per square unit of the wind turbine. In this particular area, surrounding the Vršac Mountains, the electric power obtained from wind power plants, would be about $800(789) \mathrm{kWh} / \mathrm{m}^{2}$ annually. The electric power produced in this manner is considered to be a competition to the power produced in conventional power plants. In this case, annual production per square unit of the wind turbine is $1100 \mathrm{kWh} /$ $\mathrm{m}^{2}$, which relates to the main annual wind speed of about $7 \mathrm{~m} / \mathrm{s}$. Therefore, the area of south-eastern Banat is considered as the most prosperous regarding to the production of electric power by means of renewable wind energy. The northern parts of Vojvodina are characterized by very mild air streams with main annual wind speeds of under $3.5 \mathrm{~m} / \mathrm{s}$ (Figure 2).

According to the advice of Ministry of Infrastructure and Energy of the Republic of Serbia, an economically profitable location for investments in building the wind power plants is the one with the lowest annual wind speed ranging from 4.9 to $5.8 \mathrm{~m} / \mathrm{s}$. During the last few years measurements were performed at 


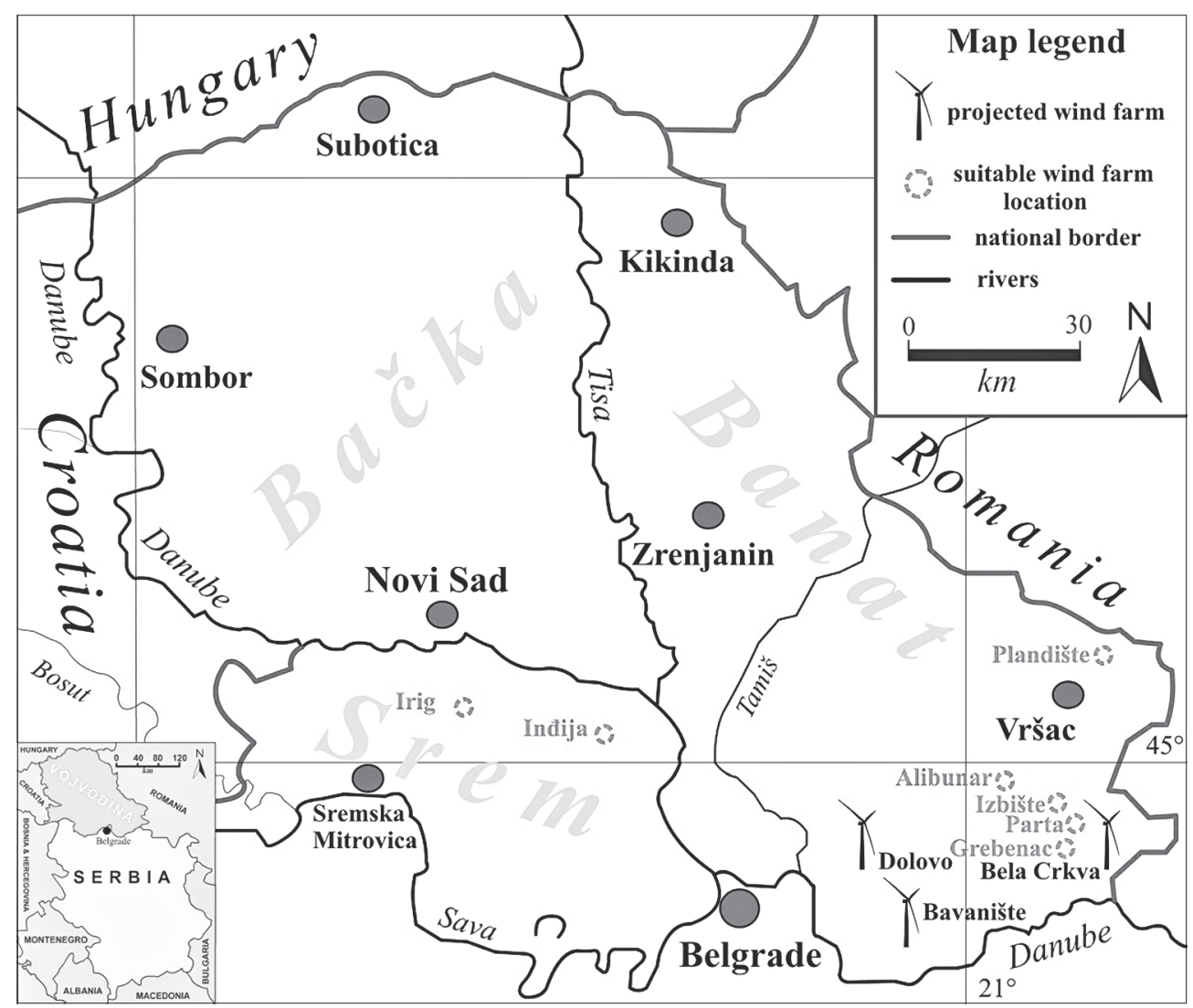

Figure 3. Locations of projected wind farms and other convenient wind farm locations in Vojvodina

several micro-locations in Vojvodina, in order to obtain precise data about future return on investments. The research needs allocations for each measurement pillar that measures wind speed at $50 \mathrm{~m}, 40 \mathrm{~m}$ and 30 $\mathrm{m}$ respectively (for the period of one to three years), air pressure and humidity. The total amount of allocations to research of wind potential varies between 10,000 and 12,000 Euros (Strategy of Energy Development in the Republic of Serbia by 2015 - for the period 2007- 2012, 2005). The price of a single wind power plant $(1 \mathrm{MW})$ is approximately equal to the installation of $1 \mathrm{MW}$ in an average coal-fired thermal power plant. On the contrary to thermal and hydropower plants, wind power plants are built very fast, in a couple of months and with the average lifetime of 25 years. The wind power plant's production is controlled solely by the wind force, whereas the production in hydro power plants is controlled by the market demands.

The recent measurements and analyses have shown cost effectiveness of building wind farms at three locations in the Vojvodina region (Figure 3). The projects have already been designed, but the adoption of certain legislation issues at state's level needs to be conducted in order to start with its realisation. The most convenient locations for installing the wind turbines are:
1. Dolovo- $48 \mathrm{MW}$ wind farm, i.e. twenty-four $2 \mathrm{MW}$ wind turbines with annual delivery of 108-149 MWh;

2. Bavanište - $100 \mathrm{MW}$ wind farm, i.e. ninety-four 1.1 MW wind turbines with annual delivery of 250 MWh;

3. Bela Crkva - $100 \mathrm{MW}$ wind farm, or $187 \mathrm{MW}$ wind farm according to certain researches (Wind Atlas of Vojvodina, 2008).

The leading energy company in the Balkans, "NIS Gazprom Neft", has signed an agreement to begin the construction of a wind farm near Plandište with Company Energowind. The above mentioned actions will lead to an implementation of major energy projects that will enable the installation of 34 wind turbines and construction of a wind park of strong potential. Wind farm Plandište will be the first wind farm in Serbia which will ensure the exploitation of the production of at least $212 \mathrm{GWh}$ of electricity per year, reducing emissions of greenhouse gases in the atmosphere. The current legislation stipulates that the electricity produced by the wind farm is to be bought by a public company Electric Power Industry of Serbia. The estimated value of the investment is approximately 160 million EUR (NIS, 2012). 


\section{Vojvodina wind energy - necessity for the Serbia electricity market}

Wind use in Serbia particularly has had its long tradition in the Vojvodina region. In the $19^{\text {th }}$ century there were around 280 windmills in Vojvodina, and the first one was built in the late $18^{\text {th }}$ century in the village of Elemir, in Zrenjanin municipality, the central parts of the Banat micro region (Tomić et al, 2004).

The region of Vojvodina, as a region of great possibilities for wind power exploitation, is characterized by several fundamental facts such as (Gburčik et al, 2006; Wind Atlas of Vojvodina, 2008; Đurišić et al, 2007):

- good wind potential in some parts of the region;

- accessibility of terrain and low building/construction cost of the wind turbines (for wind farm development);

- low transport cost, for large wind turbines and the wind turbines from the countries of the European Union (the Danube river);

- low keraunic level;

- many isolated/individual electricity consumers in the rural areas that are potential users for small wind system applications;

- creating a favourable framework for conception of an integrated renewable energy policy programs.

Today, renewable resources make $7 \%$ of total energy sources in Serbia, with 32\% of electric energy being produced in hydro power plants. Strategy of Energy sector development by 2015 has made strengthening alternative energy resources a priority issue (Strategy of Energy Development in the Republic of Serbia by 2015 - for the period 2007- 2012, 2005; Possibilities of wind energy utilization for electrical energy production, 2002).

There are several institutions in Serbia that are active (directly or indirectly) in the process of defining the conditions and the rules for doing business in the energy production sector. In most cases, organization, jurisdiction and activity of the institutions are synchronized with the existing institutional framework which is already established in the developed countries. In Serbia, this is provided by Ministry of Infrastructure and Energy, Ministry of Environment, Mining and Spatial Planning, Ministry of Agriculture, Trade, Forestry and Water Management, Ministry of Education and Science, Serbian Energy Agency, Serbian Energy Efficiency Agency, Regional Centres for Energy Efficiency, Provincial Secretariat for Energy and Mineral Resources of Vojvodina and Environmental Protection Fund (Golušin et al, 2010).

Serbian Energy Efficiency Agency, founded in 2005, coordinates the projects between the municipalities and other relevant bodies. Regarding the legal frame- work, Law on Energy is regulating energy sector and renewable energy resources, and is the only legislation act in this area. It defines privileged status for alternative energy producers which have priority for subsidizes, tax, customs and other incentives according to the law and according to other customs and tax regulations (Dodić et al, 2010).

Serbia is a country with specific features regarding the structure of primary energy which must be taken into account when it comes to the adoption of certain attitudes and design of policies to increase energy efficiency (Golušin, Munitlak-Ivanović, 2011).

The possibilities for the use of renewable energy sources in Vojvodina and Serbia in general are based on the application of the Energy Law (Official Gazette of the Republic of Serbia, No. 57/211, 80/11 - correction 93/12 and 124/12), Law on Environment protection (Official Gazette of the Republic of Serbia, No. 135/04, 36/09 - correction) and Law on planning and construction (Official Gazette of the Republic of Serbia, No. 72/09, 81/09 - correction, 64/10 - US 24/11).

Energy Law from 2011 defines the renewable resources energy production as privileged and implies transmission of such energy by introducing subsidies and implying export opportunities for alternative energy production. Electrical power producers may obtain the status of privileged electrical power producers in concordance with the Law and under the following criteria:

1. generation of electricity from renewable resources (e.g. water, wind, biomass), except hydropower plants with installed capacities over $30 \mathrm{MW}$;

2. an individual generating facility with an installed capacity of up to $30 \mathrm{MW}$ simultaneously generates electricity and heat energy (with high percentage of primary energy use);

3. the facilities are connected to the grid;

4. the facilities have separate metering stations from those measuring the electricity produced by other technological processes;

5. an agreement on the sale of heat energy for cogeneration power plants has been concluded;

6. the facility is dedicated as a wind or a solar plant with an installed capacity less than free capacity, i.e. that the request to obtain privileged producer status relates to a part of the installed power that is equal to/ or less than the free capacity.

These regulations definitely act as important incentives regarding the electricity generated from renewable wind energy. Incentive measures for utilisation of renewable resources in electricity generation in terms of this Law comprise the following: an obligation by the public supplier to purchase electricity from the privileged producer, the prices of electricity, the period of the obligation and assumption of bal- 
ance responsibility. Under provisions of this act, the public supplier is obliged to purchase the energy from the privileged producer according to the agreement on electricity purchase (Official Gazette of the Republic of Serbia, No. 57/211, 80/11 - correction 93/12 and 124/12).

A set of rules on environment protection assumes the environmental impact assessment of plans and projects and the obligatory estimation of the Institute for Environmental Protection. The Law on Planning and Construction introduced a number of novelties that relate to objects of renewable energy sources. Wind turbines may be built on agricultural land in private ownership with prior agreement on ownership and lease. These objects are an exception from the general rules for formation of building plots, as only spatial plan is the basis for issuing location permits. The production capacity objects of $10 \mathrm{MW}$ or less power, regardless of their height fall under the responsibility of the municipalities. These regulations are in support of construction of both individual wind turbines and wind farms (Serbian Transmission System and Market Operator, 2009).

In order to improve the quality of life and the protection of the environment, and to put in place the sustainable development concept that corresponds to Kyoto protocol requirements, Serbia has paid special attention to the development of energy sector. The sector of production of energy from renewable energy sources in Serbia and in the Vojvodina region is in its initial stage (Golušin et al, 2010).

There is a huge interest for wind energy production in Vojvodina. Provincial Secretariat for Energy and Mineral Resources financed the first Wind Atlas of AP Vojvodina and Executive Council of Vojvodina established the Council for the use of wind energy. Additional measurements commenced, mainly conducted by foreign investors in the following municipalities: Alibunar, Vršac, Inđija, Pančevo, Kanjiža, Irig, Kovin, Kovačica, Bela Crkva, Šid and Titel. Furthermore, it is necessary to define the locations for potential wind parks within Spatial Planning and Plans of detailed regulations of certain localities. The former studies implied construction of wind parks with the total installed power of $1.278 \mathrm{MW}$. Maximum technical possibility for wind farms implementation into electric power system according to empirical estimations is about $340 \mathrm{MW}$ (Energy Balance of the Autonomous Province of Vojvodina, 2010; Energy Balance of the Autonomous Province of Vojvodina, 2009; Energy Balance of the Autonomous Province of Vojvodina, 2008).

The current installed power of thermal power plants and cogeneration plants in Vojvodina is 425 MW, whereas permanent available power of pow- er plants is 363 MW (Wind Atlas of Vojvodina, 2008). Standard annual production of the power plants fluctuates between 650 and $780 \mathrm{GWh}$, which is substantially lower than the production capacities. The electric power needs in Vojvodina oversize 9,000 GWh (Energy Balance of the Autonomous Province of Vojvodina, 2010). Contrasted to 2010 when the energetic network received 231 GWh (Energy Balance of the Autonomous Province of Vojvodina, 2009), the year 2011 demonstrated the decreasing production trend of $25 \%$ or 191 GWh (Energy Balance of the Autonomous Province of Vojvodina, 2010). This fact highlights the need for utilisation of renewable energy resources, especially valorisation of wind power potential and its implementation for improving the efficiency of the energy sector. Provincial Secretariat for Energy and Mineral Resources coordinates all programmes and project concerning utilisation of renewable sources in Autonomous Province of Vojvodina. This implies the openness of Vojvodina for the domestic and foreign investments in building new capacities for the use of renewable energy sources and improvements of energy efficiency. Primary energy production in 2009 was $0.961 \mathrm{M}$ toe (Energy Balance of the Autonomous Province of Vojvodina, 2008), and in 2011 it was $1.509 \mathrm{M}$ toe $\left(1 \mathrm{M}\right.$ toe $\left.=11.63 \times 10^{3} \mathrm{GWh}\right)$ (Energy Balance of the Autonomous Province of Vojvodina, 2010). Production growth of primary energy in 2011 compared to 2010 was about $20 \%$, whereas compared to 2009 it was about $57 \%$. The primary energy for Vojvodina in 2011 was $3.678 \mathrm{M}$ toe, which was $1 \%$ lower than the available primary energy according to estimations for 2010 (3.718 $\mathrm{M}$ toe). The structure of energy resources remained mainly unchanged, with the highest share in the favour of fossil fuels and only $0.7 \%$ in the favour of renewable energy resources within the total needs of AP Vojvodina (Energy Balance of the Autonomous Province of Vojvodina, 2010; Wind Atlas of Vojvodina, 2008; Energy Balance of the Autonomous Province of Vojvodina, 2009; Energy Balance of the Autonomous Province of Vojvodina, 2008; Strategy of Energy Development in the Republic of Serbia by 2015 - for the period 2007-2012, 2005).

During 2011, the total primary energy available for consumption was directed towards (Energy Balance of the Autonomous Province of Vojvodina, 2010):

- energetic sector drives (0.521 M toe);

- energetic transformations in thermal power plants, cogeneration plants and refineries (1.28o $\mathrm{M}$ toe for Vojvodina, $1.398 \mathrm{M}$ toe for Serbia without Vojvodina and total $2.678 \mathrm{M}$ toe);

- directly for final consumption both energetic or non-energetic (1.738 M toe);

- recouping the transport and energy distribution losses (o.139 M toe). 

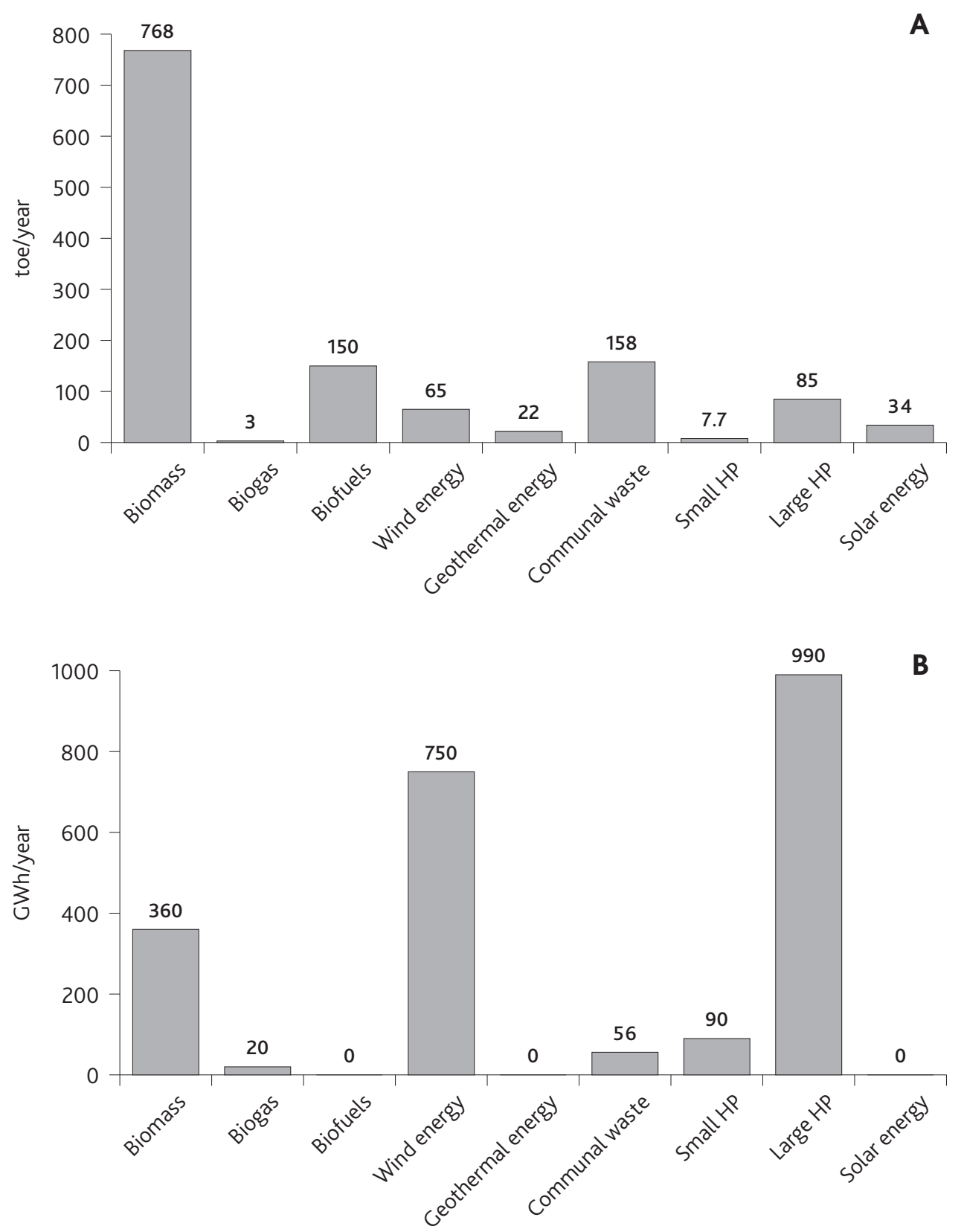

Figure 4. Total potential of renewable energy resources - A and possible production of electrical energy - B in Vojvodina (North Serbia) Source adapted from: Energy Balance of the Autonomous Province of Vojvodina, 2010; Energy Balance of the Autonomous Province of Vojvodina, 2009; Energy Balance of the Autonomous Province of Vojvodina, 2008

The figure 4 presents the total potential of renewable energy sources and their utilisation for electric power production purposes. The figure 4-A highlights that the highest potential is located in Vojvodina, for instance, according to empirical studies, for biomass and communal waste it is 768 and 158 toe per year respectively, whereas the wind energy potential is estimated to 65 toe per year. If only the renewable energy sources (excluding small hydro power plants) where primary energy is turned into electrical are taken into account, it may be concluded that the energy potential is uniform and reduced to wind energy and large hydro power plants (Figure 4-B). Such forms of renewa- ble resources are significant for electric power system of both Vojvodina and Serbia. The funds needed for installation of $300 \mathrm{MW}$ wind power plants, according to the studies of Provincial Secretariat for Energy and Mineral Resources of Vojvodina, are approximately 300 million US dollars. The projected annual power production by means of wind energy would be 750 GWh. The energy obtained in such way would have significant share in the total primary energy, available not only for consumption, directed towards the production in energetic sector, for energetic transformations, for direct final consumption for energetic or non-energetic purposes, but also for covering losses 
(Energy Balance of the Autonomous Province of Vojvodina, 2010).

\section{Conventional energy vs. Renewables - the true cost of electricity}

The conventional energy - nuclear power, fossil fuels such as hard coal and lignite have been receiving considerable state subsidies for decades as financial contributions and tax incentives along with other favorable treatment. The main difference from the cost of renewables is that a lot of these costs for conventional power are not separately reported in power prices and paid in power bills. Instead, they are part of the governmental budget (BWE, 2012).

For instance Germany is the EU country with the largest installed wind power capacity - (EWEA, 2012). Researchers from German Wind Energy Association (BWE) have taken a closer look at extra costs of electricity. The resulting price of a kilowatt-hour ( $\mathrm{kWh}$ ) of wind power for society in 2012 was 8.1 cents, compared to $7.6 \mathrm{c} € / \mathrm{kWh}$ for hydropower. In contrast to that, the total cost of power from lignite and hard coal add up to 15.6 and $14.8 \mathrm{c} € / \mathrm{kWh}$. With the calculated value from the spectrum of external costs $(34.3 \mathrm{c} € /$ $\mathrm{kWh}$ ), the cost of nuclear power to society reaches 42.2 $c € / \mathrm{kWh}$. The cost of electricity from natural gas is 9.0 $\mathrm{c} € / \mathrm{kWh}$ (BWE, 2012). This is important for future investments and implementation concepts of wind energy exploitation in the Vojvodina region.

\section{Positive and negative aspects of policy planning and wind energy implementation concept in Vojvodina region}

Basic precondition for planning and construction of wind power plants is technical efficiency of wind energy potential (Wizelius, 2007). Apart from this, there are other necessary technical preconditions for wind power plants operation. In order to efficiently supply consumers with electricity, a wind power plant of higher power capacity must be connected to either the power transmission grid or the power distribution grid. Electrical energy is not found alone as a source of energy in nature, but generated by conversion of other energy resources; the transmission possibility to deliver it to consumers is one of its characteristics. The electric energy system needs to be balanced, i.e. to equal the production and consumption (Beurskens, Jensen, 2001). Such imbalance leads to changes in voltage frequencies on the grid which may result in system failure caused by stronger disturbances. Wind is the energy source with changing power over time and unpredictable changes on a long term basis. Since these relevant wind features do not allow proper manage- ment of the wind power plant production, it is managed by current status of the wind. The connection of the wind power plant to the grid implies that the system includes the power plants that enable the delivery of balanced energy. The possibility of balanced energy delivery in an electric energy system depends on the system's features, first of all energy resources used by power plants within the system (Poullikkas, 2007). Development Plan of the electrical network of Serbia for the period until 2014 envisages the construction of new $400 \mathrm{kV}$ and $110 \mathrm{kV}$ transmission lines, as well as cross-border network connectivity that could provide the conditions for the wind power plants construction and connection to the network (Serbian Transmission System and Market Operator, 2009).

Serbia is a member of the South East Europe Energy Community, and its international obligations encourage the use of renewable energy sources, especially the use of wind energy. The delay in the construction of wind turbines has a positive side. In forming policy and the construction of wind turbines, Serbia can use more than two decade experiences of countries with developed wind engineering. Germany, Spain, Italy, France, Great Britain and Denmark are leading in the use of wind energy among European countries (EWEA, 2012). Practical policies pursued by these countries have encouraged this form of electricity generation and their policies in this sector can be characterized as positive. Measures implemented in some countries, which have resulted in slowdown or delay in the development of wind engineering and the creation of various barriers, may be characterized as negative policy. The main difference of positive and negative policies is in the stimulatory mechanisms, spatial planning and the efficiency of the licensing procedure for wind turbine construction.

Of all the methods used so far as economic support, the system of subsidized price of electricity produced by using renewable energy sources, the so-called "feed-in" tariff system, proved to be the most successful. This system was applied in Denmark, Germany and Spain (EWEA, 2012). In the region of Vojvodina (North Serbia) this system indicates that purchaser shall pay to the Producer in respect of a Calculation Period in arrears 0.95 euro cents as the relevant tariff of the Decree on Incentives for Production of Electricity from Renewable Energy Sources and Combined Heat and Power Production (Official Gazette of the Republic of Serbia, No. 57/211, 80/11 - correction 93/12 and 124/12) until replaced with the Government Decree and in accordance with specified Euro CPI index for each kWh of electrical output and deemed output in such calculation period. System variance that prescribes the quota that is maximum total power of power plants producing energy from renewable sourc- 
es, subsidised by the state has shown to be inconvenient (Ministry of mining and energy the Republic of Serbia, 2010).

Spatial planning essentially affects the extent of use of renewable energy sources and the development speed of this sector. There are 4 factors that contribute to successful use of renewable energy sources (Wizelius, 2007):

1. well-designed payment mechanism for the produced energy;

2. transmission and distribution network access and network development;

3. simple and well-defined administrative licensing procedure;

4. support and acceptance by the public.

Spatial planning method is very important for the successful use of wind energy, where a conflict of interest is common occurrence. The use of wind energy in spatial planning has a very positive global effect on the environment. Some negative effects become prominent on the local level, such as noise, light reflection, the impact on telecommunications, the impact on birds and bats, and the visual impact on the landscape (Josimović, Pucar, 2010). The planning that commences at states' level and continues on regional towards local level has proved to be a negative policy in this sector. Such planning method has significantly slowed the development or created barriers for the use of wind energy in countries where applied.

The approach based on planning on the local unit level on which the construction of wind turbines has the greatest influence has proved to be a positive policy. The method of "round table" on the municipal lev$\mathrm{el}$ is one of the most effective methods.

Manufacturers of energy from renewable energy sources can gain privileged status on the basis of the Decree on Incentive Measures for the Production of Electricity by Using Renewable Energy and Combined Production of Electricity and Thermal Energy. The same act defines that the buyer of electricity from renewable energy sources is Electric Power Industry of Serbia (EPS). The regulation on feed-in tariff system determines the fixed price of $9.5 \mathrm{c} € / \mathrm{kWh}$ of electricity produced by using wind force (Official Gazette of the Republic of Serbia, No. 57/211, 80/11 - correction 93/12 and 124/12). The effectiveness of this incentive depends on the energy potential of wind at the selected location. Public Enterprise Electrical network of Serbia (EMS) has made a plan for the development of transmission system by 2014 which considers planning the forms and dates for the connection to wind turbines (Serbian Transmission System and Market Operator, 2009).

With regard to the spatial planning aspect, the largest number of wind turbines is planned in the area of
Southern Banat. Certain municipalities in this area have adopted spatial plans including graphical display of the area for wind farm construction. The Institute for Nature Protection in Vojvodina has launched an initiative for the preparation of higher-order spatial plan which would define the areas for wind park construction.

The document "Establishment of an ecological network in AP Vojvodina - Overview of the status, analysis and opportunities" (Institute for Nature Protection in Serbia, 2009) contains a section "Wind farms and protection of biodiversity", which refers to wind farm impact on ornithofauna and chiroptera fauna. If in proceedings following the proposal for the development of a Regional spatial plan of South Banat, an interpretation is adopted in which the area of "high threat for birds from wind power plants" is a forbidden area for wind farm construction, the conclusion is as follows: In Vršac, the municipality which has the highest wind energy potential, the use of wind energy is not allowed. This confirms that the negative policy of wind farms spatial planning or the top-down (from states' to local level) development of plans based on some general rules, creates a barrier to the use of wind energy. On the other hand, positive planning policy envisages local level planning with taking all necessary precaution measures to protect birds and the environment in general. A case study that was applied in the Strategic Environmental Assessment (SEA) of the Urban Plan for wind power plants in Bavanište deals with the experience in the making of urban planning documentation for the first wind power plant in Serbia from the aspect of possible environmental conflicts related to the utilization of alternative energy sources - preservation of natural resources. This presents a good foundation for establishing adequate measures for environmental protection and positive approach to natural resources management (Josimović, Pucar, 2010).

The process of obtaining the civil engineering licence for building a wind farm contains uncertainties regarding the jurisdiction and procedure. Ministry of Environment Protection, Mining and Spatial Planning offered interpretation and instructions to eliminate uncertainties. The first step within the procedure is obtaining the energetic certificate (Official Gazette of the Republic of Serbia, No. 57/211, 80/11 - correction 93/12 and 124/12). Under the condition that the area of the planned wind farm is included in the spatial plan of the municipality, long term procedure of the detailed regulation plan for wind turbines installation is not necessary. However, the infrastructure objects such as roads and transmission towers need the planned documentation. Although the procedure of obtaining the civil engineering licence is long 
termed and complex, there are regulations that enable it (Ministry of mining and energy the Republic of Serbia, 2010). Substantial uncertainties are linked to regulations on environment protection and adoption of positive policy.

\section{Conclusion}

Vojvodina represents a region of special interest for wind energy consumption. This area, especially the south-eastern parts of Banat micro region is very favourable for the construction of wind power plants for the purpose of use of wind energy. This construction should be realized in phases, in the course of which it would constantly be necessary to monitor the technical efficiency and the economy of the already built capacities and accordingly correct the future dynamics of the construction of wind power plants. Regardless of the chosen strategic model of the development of electric energy system, there will always be a need, and most probably an obligation for the use of ecologically clean energy sources in the near future. Energy efficiency, which is actually a question of competitiveness of each economy, can finance itself through the mechanisms of the Kyoto Protocol (Golušin, Munitlak-Ivanović, 2011) which Serbia pretends to implement in its legislation framework. Vojvodina has a solid wind potential which must be used for the production of electrical energy and stabilization of energy sector in Serbia's northern province. Moreover, the minor role of renewable energy sources (except bio fuel and hydro potential) with a regard to the total provided energy in Vojvodina, reflects the need for more efficient assessment and production of energy from alternative resources, since Serbia frequently "borrows" power from energy system of Central Serbia and imports electric power from abroad as well. The wind and the hydro energetic potentials might produce approximately 1.750 GWh annually, which is a significant inflow for the energetic sector of Serbia. In relation to this, there are several locations (in southeast Banat) with determined wind energy potential and several more suitable locations that can be very prosperous sites for modern wind power plant installation, which could produce electric energy to meet the needs of electricity market in Serbia.

Clearly, a few types of renewable power (e.g. wind power) are already much cheaper than conventional electricity once we include not only the power price, but also the cost of state subsidies, the impact on the environment and climate, and nuclear risks - a factor that should be taken into account in the discussion about affordable power and the debate about Serbia's future energy supply. The new Law on Energy and preparation procedure for adoption of the Law on rational energy use represent a positive step towards creating a platform that would contribute to a better planning within the energy sector, particularly regarding promotion of renewable energy sources and their efficient use. Under the condition that the Fund for energy efficiency and renewable resources were established, it would be the incentive for broader utilisation of renewable energy sources of all types both in Vojvodina and Serbia.

On one side there is a conflict of interest in Vojvodina between sustainable development in energy sector that would be achieved by building wind power plants in the area of the highest energy potential, and on the other insisting on building prohibition in this area by the regional spatial plan of South Banat. The crucial role in the resolution of the conflict between wind turbines influence on the local area and their installation in concordance with sustainable development should be assigned to the local authorities, i.e. the population that has long tradition of using wind force.

\section{Acknowledgement}

This work is supported by the Ministry of Education, Science and Technological development, Republic of Serbia (grants 176020 and 43002).

\section{References}

Awerbuch, S. 2006. Wind Economics in 21st Century. New Energy - Magazine for Renewable energy, $1,44-47$

Baños, R., F. Manzano-Agugliaro, F., Montoya, F.G., Gil, C., Alcayde, A., Gómez, J. 2011. Optimization methods applied to renewable and sustainable energy: A review. Renewable and Sustainable Energy Reviews, 15, 1753-1766.

Beurskens, J., Jensen, P. H. 2001. Economics of wind energy, Renewable Energy World, 4, 103-121.

BWE 2012. The full costs of power generation.

Chen, F., Duic, N., Alves, L.M., Carvalho, M.d.G. 2007. Renewislands-renewable energy solutions for islands. Renewable and Sustainable Energy Reviews, 11, 1888-1902.

Dodić, S. N., Vučurović, G. D., Popov, D. S., Dodić, M. J., Zavago, Z. Z. 2010. Concept of cleaner production in Vojvodina. Renewable and Sustainable Energy Reviews, 14, 1629-1634.

Đurišić, Ž., Bubnjević, M., Mikičić, D., Rajaković, N. 2007. Wind Atlas of Serbian Region Vojvodina. Proc. of European Wind Energy Conference EWEC.

Energy Balance of the Autonomous Province of Vojvodina for 2011. (2010). Provincial Secretariat of Energy and Mineral Resources, Novi Sad. 
Energy Balance of the Autonomous Province of Vojvodina for 2010. (2009). Provincial Secretariat of Energy and Mineral Resources, Novi Sad. (in Serbian)

Energy Balance of the Autonomous Province of Vojvodina for 2009. (2008). Provincial Secretariat of Energy and Mineral Resources, Novi Sad. (in Serbian)

Energy Law. Official Gazette of the Republic of Serbia, No. 57/211, 80/11 - correction 93/12 and 124/12). (in Serbian)

EWEA 2012. European statistics.

Gburčik, P., Gburčik, V, Gavrilov, M, Srdanović, V., Mastilović, S. 2006. Complementary Regimes of Solar and Wind Energy in Serbia. Geographica Pannonica, 10, 22-25.

Golušin, M, Tešić, Z., Ostojić, A. 2010. The analysis of the renewable energy production sector in Serbia. Renewable and Sustainable Energy Reviews, 14, 1477-1483.

Golušin, M., Munitlak-Ivanović, O. 2011. Kyoto Protocol implementation in Serbia as precognition of sustainable energetic and economic development. Energy Policy, 39, 2800-2807.

Ilkilic, C., Turkbay, I. 2010. Determination and utilization of wind energy potential for Turkey. Renewable and Sustainable Energy Reviews, 14, 2202-2207.

Institute for Nature Protection in Serbia 2009. Ecological Network Implementation in Autonomous Province of Vojvodina - Status Review, Analysis and Potentials. (in Serbian)

Josimović, B., Pucar, M. 2010. The strategic environmental impact assessment of electric wind energy plants: Case study "Bavanište" Serbia. Renewable Energy, 35, 1509-1519.

Kaygusuz, K. 2011. Wind energy status in renewable electrical energy production in Turkey. Renewable and Sustainable Energy Reviews, 14, 2104-2112.

Komarov, D., Stupar, S., Simonović, A., Stanojević, M. 2012. Prospects of wind energy sector development in Serbia with relevant regulatory framework overview. Renewable and Sustainable Energy Reviews,16, 2618-2630.

Lalić, D., Popovski, K., Gecevska, V., Popovska-Vasilevska, S., Tešić, Z. 2010. Analysis of the opportunities and challenges for renewable energy market in the Western Balkan countries. Renewable and Sustainable Energy Reviews, 15, 3187-3195.
Law on Environmental protection. Official Gazette of the Republic of Serbia, No. 135/04, 36/09 - correction). (in Serbian)

Law on Planning and Construction. Official Gazette of the Republic of Serbia, No. 72/09, 81/09 - correction, 64/10 - US 24/11). (in Serbian)

Li, H., Chen, Z. 2009. Design optimization and site matching of direct-drive permanent magnet wind power generator systems. Renewable Energy, 34, 1175-1184.

Ministry of mining and energy the Republic of Serbia 2010. Construction Of Wind Farms And Electricity Generation From Wind Energy in the Republic of Serbia - Guide For Investors.

NIS. 2012. Report on Sustainable Development.

Peidong, Z., Yanli, Y., Yonghong, S.j.Z., Lisheng, W., Xinrong, L. 2009. Opportunities and challenges for renewable energy policy in China. Renewable and Sustainable Energy Reviews, 13, 439-449.

Project "Atlas of solar and wind energetic potential in Serbia“'TD-7042B. 2007. Ministry of Science of the Republic Serbia, Institute of the multidisciplinary studies. (in Serbian)

Possibilities of wind energy utilization for electrical energy production 2002. Electric Power Industry of Serbia, TEKON, Republic Hydrometeorological Service of Serbia. (in Serbian)

Poullikkas, A. 2007. Implementation of distributed generation technologies in isolated power systems, Renewable and Sustainable Energy Reviews, 11, 3056.

Serbian Transmission System and Market Operator 2009. Development plan of transport system by 2014. (in Serbian)

Strategy of Energy Development in the Republic of Serbia by 2015 - for the period 2007- 2012. 2005. Belgrade. (in Serbian)

Tomić, P., Romelić, J., Kicošev, S., Lazić, L. 2004. Vojvodina - scientifically-popular monograph, second edition. Geographic Society of Vojvodina, Novi Sad. (in Serbian)

Tükenmez, M., Demireli, E. 2012. Renewable energy policy in Turkey with the new legal regulations. Renewable Energy, 39, 1-9.

Wind Atlas of Vojvodina. 2008. Faculty of Technical Sciences, Novi Sad. (in Serbian)

Wizelius, T. 2007. Developing Wind Power Projects. Earthscan, UK. 